\title{
Die gelykenisse van Jesus: Allegorieë of simbole van sosiale transformasie?
}

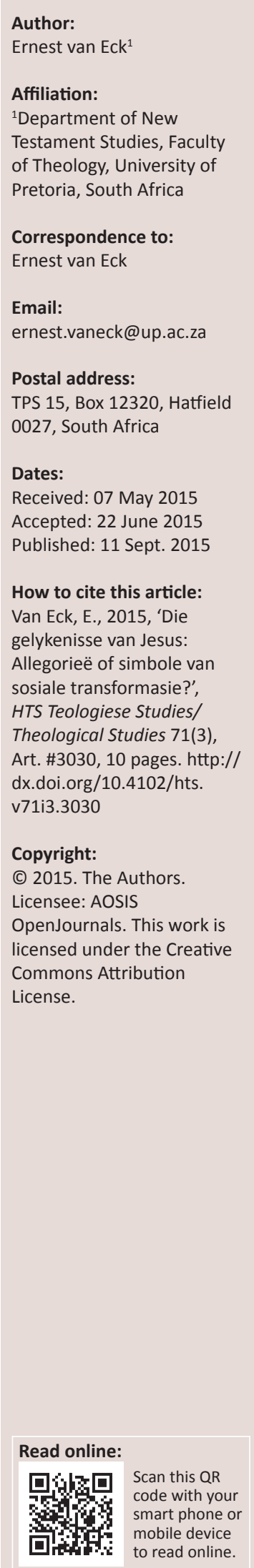

The parables of Jesus: Allegories or symbols of social transformation? This article reflects on a possible methodology that can be used to interpret the parables of Jesus preserved in the Synoptics (and the Gospel of Thomas). It is argued that the available versions of the parables of Jesus have already been allegorised, and that this should be taken into consideration when the extant versions of parables are interpreted as parables of the historical Jesus. The parables should also, as far as possible, be interpreted against the social realia evoked by the parables. In this endeavour, Roman-Egypt inscriptions and papyri are in most cases the only sources available. The article concludes with a few examples, illustrating the possibilities of interpretation when the proposed methodology is applied.

\section{Inleidende opmerkings}

Die interpretasiegeskiedenis van die gelykenisse dui daarop dat gelykenisnavorsers in die meeste gevalle die gelykenisse van Jesus, soos hulle in die Sinoptiese evangelies en die Evangelie van Tomas oorgelewer is, ongedifferensieerd aan die historiese Jesus toedig. Die insig wat ontbreek, is die feit dat die vroegste allegoriserings van Jesus se gelykenisse nie by die vroeë kerkvaders gevind word nie, maar by die Sinoptici self. ${ }^{1}$ Om die gelykenisse tot ons beskikking as gelykenisse van Jesus te interpreteer, is dit daarom nodig dat daar bewustelik met die verskil tussen die literêre en sosiale kontekste van die gelykenisse omgegaan word. ${ }^{2}$

Dit is verder ook belangrik om die gelykenisse te probeer verstaan in terme van die kulturele raamwerk en ervarings van die aanvanklike hoorders van Jesus se gelykenisse. RomeinsEgiptiese inskripsies en papiri bevat ' $n$ magdom inligting wat die moderne interpreteerder van die gelykenisse kan help om iets van hierdie kulturele raamwerk en ervarings te verstaan. Deur die gebruik van 'n sosiaalwetenskaplike benadering kan die sosiale realia wat 'agter' (en in) die gelykenisse lê, en waarvan beskikbare inskripsies en papiri getuig, kultuursensitief verstaan word.

In wat volg, word hierdie uitgangspunte as vertrekpunt gebruik om 'n bepaalde metodologie daar te stel wat gebruik kan word om die allegoriese reste van die oorspronklike gelykenisse van Jesus as gelykenisse van Jesus te ondersoek. As illustrasie van die voorgestelde metode, word afgesluit met drie voorbeelde as resultaat van die toepassing van die voorgestelde metodologie.

\section{Die allegorisering van die gelykenisse}

Die allegorisering van die gelykenisse kom in wese daarop neer dat 'n bepaalde betekenis aan 'n gelykenis toegedig word wat nie die bedoeling van die gelykenis is nie. Feitlik alle gelykenisnavorsers is dit eens dat die allegorisering van gelykenisse plaasvind omdat die gelykenisse geïnterpreteer word deur die hermeneutiese lens van latere dogmatiese of (dikwels onbewustelik) eietydse teologiese oortuigings (kyk Van Eck 2014b:2; 2015b). ${ }^{3}$ Daar is verder

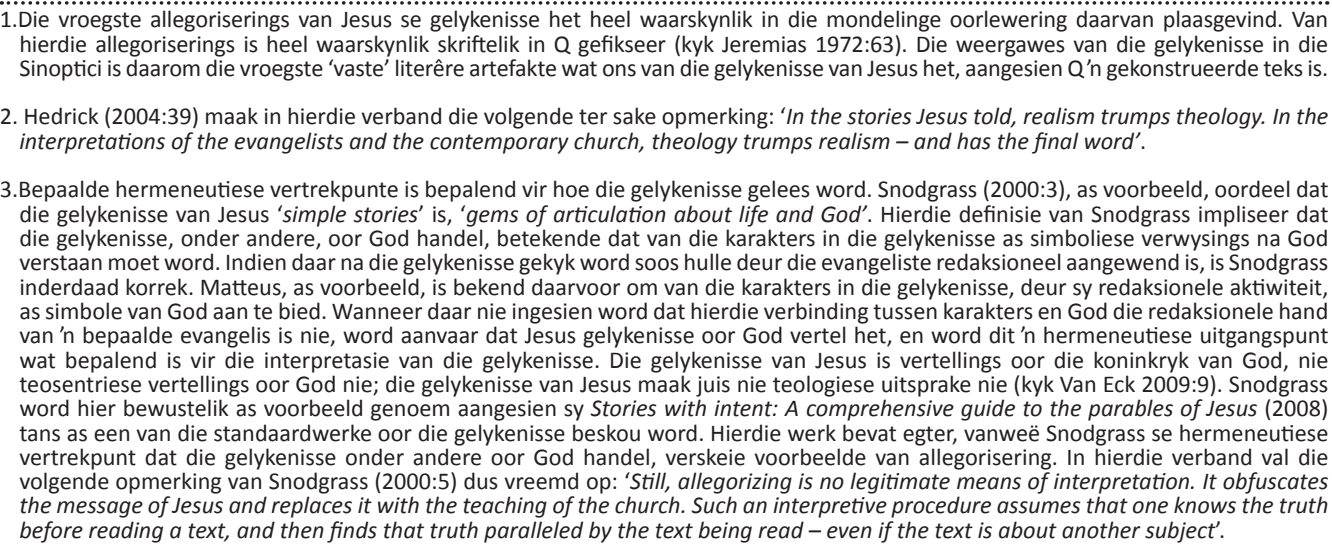


eenstemmigheid dat die allegorisering van die gelykenisse sy oorsprong in die interpretasies van die vroeë Kerkvaders gehad het, met Irenaeus (130-202 n.C.) as die vroegste voorbeeld. ${ }^{4}$

Die feit van die saak is egter dat die beginpunt van die allegorisering van die gelykenisse nie by die kerkvaders lê nie, maar by die evangeliste self. Hierdie stelling, wat heel waarskynlik deur die meeste gelykenisnavorsers as pedanties beskou sal word, verdien begronding, en daarom die volgende voorbeelde. As eerste voorbeeld kan die Sinoptici se weergawes van die gelykenis van die Huurders (Mark 12:1-12//Matt 21:33-46//Luk 20:9-19), wat deel uitmaak van die trippel-tradisie, gebruik word. Die gelykenis van die Huurders kom ook in die Evangelie van Tomas 65:1- 8 voor, wat heel waarskynlik die weergawe verteenwoordig wat ons die naaste aan die tradisielaag van die historiese Jesus bring, veral op grond daarvan dat Jesus in hierdie weergawe nie geweld en vergelding kondoneer nie (Van Eck 2007:909-936; kyk ook Q 6:29). In die gelykenis word die eienaar (en verhuurder) van die wingerd se eer en eienaarskap uitgedaag deur huurders wat nie sy ooreengekome deel van die oes aan hom oorhandig nie. Die eienaar se reaksie is om, teen alle verwagtings in, nie tot geweld oor te gaan om die situasie op te los nie. In die Sinoptici se aanwending van die gelykenis handel dit egter nie meer oor ' $n$ eienaar wat ' $n$ wingerd verhuur en ' $n$ dispuut oor die verdeling van die oes nie. Markus allegoriseer die gelykenis deur die gebruik van Jesaja 5:1-7 as interteks. In sy weergawe verteenwoordig die eienaar God, die huurders die Joodse tempelowerhede, die wingerd Israel, die slawe wat gestuur word die profete wat God in die verlede gestuur het, die geliefde seun Jesus, die vrug van die wingerd die reaksie wat God van Israel verwag, en die doodmaak van die slawe die val van die tempel. In die Matteaanse weergawe (Matt 21:33-46) val die klem op Jesus se konflik met Jerusalem se elite, en word die gelykenis apologeties aangewend om 'n verduideliking aan te bied vir die val van die tempel onder Titus in 70 n.C. Lukas 20:9-19, ten slotte, gebruik die Huurders om die kontras tussen Israel (die landvolk) en hulle leiers (die tempel-elite) te teken, en 'n beginsel van oordeel daar te stel (kyk Van Eck 2008:1752-1753). Al drie die Sinoptici weergawes is dus 'n allegorisering van die gelykenis.

Die tweede voorbeeld, geneem uit die dubbel-tradisie, is die gelykenis van die Verlore Skaap (Q 15:4-5; Luk 15:4-6/ / Matt 18:12-13). In die Lukaanse weergawe word die verlore skaap, in die lig van Lukas 15:1-2, allegories verstaan as een van die 'sondaars' saam met wie Jesus eet en drink. In Matteus, in die lig van Matteus 18:1-6, word die verlore skaap allegories verbind aan een van die 'kleintjies' in die geloofsgemeenskap aan wie Matteus sy evangelie rig. Die verlore skaap is dus nie meer 'n skaap nie, maar 'n simboliese verwysing na óf 'n sondaar óf 'n 'kleintjie'.

4.Kyk Wailes (1987) vir'n omvattende oorsig van die allegorisering van die gelykenisse deur die kerkvaders en in die tydperk van die Middeleeue.
As twee laaste voorbeelde kan op twee Sondergutgelykenisse gewys word, naamlik die gelykenis van die Middernagtelike Vriend (Luk 11:5-8) en die gelykenis van die Onvergewensgesinde Slaaf (Matt 18:23-35). In die eersgenoemde geval wend Lukas die gelykenis aan in die konteks van gebed (Luk 11:1-13), en allegoriseer so die gelykenis as voorbeeld van hoe gebid moet word. In die geval van Matteus 18:23-35, plaas die evangelis die gelykenis net ná Petrus se vraag in Matteus 18:21-22 oor hoeveel maal daar vergewe moet word, en sluit die gelykenis af met redaksionele kommentaar in Matteus 18:35, naamlik dat God nie sonde sal vergewe indien sondaars mekaar nie wil vergewe nie. Die skuld van die skuldenaar aan die koning, asook dié van die ander skuldenaar in die gelykenis, word so allegories omvorm tot sonde teenoor God en die naaste.

Hierdie voorbeelde maak dit duidelik dat die allegoriese interpretasies van die gelykenisse reeds by die evangeliste begin het, en nie eers by die vroeë kerkvaders nie. Verder maak bogenoemde voorbeelde dit ook duidelik dat die allegorisering van die gelykenisse deur die evangeliste nie maar net geleë is in aanduibare allegorieë soos Markus 4:13-20 (en par.) nie. Deur van die gelykenisse saam te groepeer (bv. Mark 4:1-32 en Matt 13:31-50), die gelykenisse van bepaalde kontekste te voorsien en redaksioneel aan te pas, is die gelykenisse van Jesus allegories aangewend as onderskrywing van hulle onderskeie narratiewe oor Jesus.

Wanneer hierdie aspek van die gelykenisse in die evangelies nie in ag geneem word nie, is die gevolg die verskynsel wat te dikwels in die interpretasies van die oorgrote meerderheid van gelykenisnavorsers aangetref word: Die Sinoptici se allegoriese aanwending van 'n bepaalde gelykenis word geinterpreteer as 'n gelykenis van Jesus, en nie as 'n gelykenis van byvoorbeeld die Matteaanse of Lukaanse Jesus nie. So word verlore skape afgedwaalde gelowiges, geldelike skuld word sonde, wingerde word Israel, verhuurders van wingerde word God, en huurders word die tempel-elite. Enige interpretasie van 'n gelykenis wat van die vooronderstelling uitgaan dat die historiese Jesus in die gelykenisse in die evangelies aan die woord is - en dat daar tog net teen 'n allegorisering van die betrokke gelykenis gewaak moet wordis in wese reeds allegories. Die rede hiervoor is eenvoudig; die interpretasie is gebaseer op 'n gelykenis wat alreeds 'n allegoriese interpretasie en toepassing van 'n gelykenis van die historiese Jesus verteenwoordig. ${ }^{5}$

Daar is natuurlik nie wesenlik fout daarmee om die gelykenisse in byvoorbeeld Lukas as gelykenisse van die Lukaanse Jesus te ondersoek nie. Inteendeel, sodanige ondersoek is van essensiële belang wanneer die teologie van Lukas die fokus van die ondersoek is. In so 'n ondersoek moet daar egter versigtig met terme en die toepaslikheid van die resultate van die ondersoek omgegaan word - iets wat ongelukkig ontbreek in van die beste publikasies oor die

5. Kloppenborg (2014b:490) maak in hierdie verband die volgende opmerking wat te sake is: 'Few nowadays would defend the preposition that Jesus was an allegorist, sake is: 'Few nowadays would defend the preposition that Jesus was an allegorist,
speaking in one discursive realm but in fact intending to evoke other discursive realms, for example, salvation history or the care of the soul.' 
interpretasies van die gelykenisse (kyk bv. Blomberg 2012; Hultgren 2000; Snodgrass 2008).

\section{Die gelykenisse van Jesus: Metodologiese vertrekpunte Literêre kontekste en sosiale konteks}

Die opmerkings oor die allegorisering van die gelykenisse deur die Sinoptici hierbo het alreeds die eerste metodologiese vertrekpunt, indien die fokus van die interpretasie die gelykenisse van die historiese Jesus is, gesuggereer: die gelykenisse moet nie in hul literêre kontekste nie, maar in hul sosiale konteks gelees word. Hedrick (2004) druk hierdie belangrike metodologiese vertrekpunt soos volg uit:

\begin{abstract}
What is at issue ... is where ... the reading of a parable begins.... If one is interested in the evangelist's understanding of the parable, reading begins with the literary context, but if one is interested in the parable in the context of Jesus' public career some forty years or so earlier than the gospels, reading begins with the parable and ignores the literary setting. Those who begin with the literary setting proceed on the assumption that the literary context of the parable in the gospels (usually around and after 70 C.E.) accurately reflects the social context in the public career of Jesus (around 30 C.E.).... Jesus' invention of the parable in the social context of first-century life preceded the writing of the Gospels. (bl. Xvi; [beklemtoning in die oorspronklike])
\end{abstract}

Met sosiale konteks word hier nie bedoel die spesifieke konteks waarin Jesus 'n betrokke gelykenis vertel het nie. Jeremias $(1972: 38,139)$ is byvoorbeeld van oordeel dat die gelykenis van die Werkers in die Wingerd (Matt 20:1-15) deur Jesus vertel is in 'n konteks waar die Fariseërs (verteenwoordig deur die werkers in Matt 20:11-12) Jesus gekritiseer het oor sy gewoonte om saam met tollenaars en sondaars te eet. Hierdie spesifieke kontekste waarin Jesus die gelykenisse sou vertel het, kan nie geïdentifiseer word nie, en is nie wat hier bedoel word met die sosiale konteks van die gelykenisse nie. Met sosiale konteks word hier verder ook nie bedoel die kontekste (kontekstuele wêrelde) waarin die evangeliste die gelykenisse van Jesus oorvertel het nie. ${ }^{6}$ Die konteks van die Lukaanse gemeenskap, as voorbeeld, is heel waarskynlik 'n stedelike omgewing iewers in Klein-Asië in ongeveer 96 n.C., 'n sosiale konteks wat daadwerklik verskil van die sosiale konteks waarin Jesus die gelykenisse vertel het.

Met sosiale konteks word hier bedoel die sosio-kulturele, politieke, godsdienstige en ekonomiese realiteite van die wêreld waarin Jesus en die eerste hoorders van sy gelykenisse geleef het. Wat was hierdie realiteite? Logies kan daar in die bestek van dié artikel nie volledig op hierdie sake ingegaan word nie, maar die volgende bondige opmerkings behoort ' $n$ genoegsame, oorsigtelike beeld te gee van die wêreld waarin Jesus die gelykenisse vertel het. Jesus vertel sy gelykenisse in die periode 27-30 n.C. in 'n Joodse Palestina (die mees waarskynlike op die Galilese platteland),'n gevorderde agrariese samelewing onder indirekte beheer van die Romeinse Ryk. Agrariese samelewings was aristokraties van aard, bestaande uit die elite (regeerders en dié met status en eer) en die nie-elite (landvolk). Die elite het ongeveer een tot twee persent van die bevolking uitgemaak en in die stede gewoon, terwyl die res van die bevolking bestaan het uit kleinboere (landvolk of nie-elite) wat op die platteland gewoon het. Aristokratiese samelewings het nie iets soos 'n middelklas geken nie, en ongeveer die helfte tot twee derdes van alle rykdom was in die hande van die elite. Hierdie rykdom is bekom deur beheer uit te oefen op grondbesit en produksie deur middel van verskeie vlakke van belasting, huur, rente en tol. In Galilea, byvoorbeeld, het dié soort beheer die gevolg gehad dat die kleinboere toenemend nie al hulle 'verpligtinge' kon nakom nie, wat beteken het dat hulle hul kleinhoewes verloor het, 'n situasie wat 'n geweldige impak op hulle tradisionele leefwyse gehad het. Die meeste van die landvolk het skaars op die broodlyn gelewe, en 'n stryd om oorlewing was aan die orde van die dag.

Godsdienstig gesproke was die tempel-aristokrasie in beheer van die tempel deur die grasie van indirekte regering, wat beteken het dat die eie plaaslike godsdiens beoefen kon word solank as wat daar aan die politieke en ekonomiese eise van Romeinse keiser voldoen is. Hierdie situasie het die tempel-elite in staat gestel om sekere tradisies wat vir hulle van belang was (bv. die betaal van tiendes, offers en heffings) te versterk en te herbevestig. Die belangrikste instrument in die hande van die tempel-elite was die sogenaamde 'Groot Tradisie', 'n interpretasie van die Tora wat klem gelê het op reinheid (godsdienstig en sosiaal) en die gee van tiendes en offers. Hierdie interpretasie het die tempel-elite, soos die Herodiaanse elite, in staat gestel om die kleinboere tot eie voordeel uit te buit. ${ }^{7}$

Wat betref die sosio-kulturele aspekte van die wêreld waarin Jesus die gelykenisse vertel het, die volgende: Die mees dominante waarde (skaarsste middel) was eer en skaamte. Eerste-eeuse persoonlikheid was diadies en groepgeoriënteerd, en die vermeerdering van alle middele is as beperk beskou. ' $n$ Vermeerdering van middele, op grond van hierdie beskouing, het altyd ten koste van ander plaasgevind, en daarom is diegene met welvaart as diewe beskou. Verhoudinge tussen beskermheer en onderdaan was die senuwee wat die samelewing aan die gang gehou het, en al wyse waarop die nie-elite toegang tot sekere middele en dienste kon verkry. Etes is as seremonies beskou (die herbevestiging van gedeelde waardes), en 'n duidelike onderskeid is getref tussen wat as rein en onrein (kulties en sosiaal) beskou is (kyk Malina 1981, 1986; Malina \& Rohrbaugh 2003).

\section{Die noodsaak van 'n kultuursensitiewe lees van die gelykenisse}

Die enkele (en totaal onvoldoende) opmerkings in § 3.1 oor die sosio-kulturele wêreld waarin Jesus die gelykenisse

7.Vir die omvangryke literatuur waarop hierdie opsommende opmerkings gebaseer is, kyk Van Eck (2008:1738-1743; kyk ook Van Eck 2009:4-5). 
vertel het, maak dit duidelik dat 'n kultuursensitiewe lees van die gelykenisse uiters noodsaaklik is om hul moontlike betekenisse op 'n verantwoordelike wyse te ontsluit. Om die verskil te misken tussen die kultuur van die moderne interpreteerder en die kultuurwêreld wat in die gelykenisse verbeeld word, lei eenvoudig tot anakronistiese en/ of etnosentriese interpretasies van die gelykenisse. ${ }^{8}$ Die mees geskikte hermeneutiese benadering wat 'n kultuursensitiewe lees van die gelykenisse moontlik maak, is heel waarskynlik die sosiaalwetenskaplike benadering. ${ }^{9}$ Die basiese uitgangspunt van die sosiaalwetenskaplike benadering tot die lees van antieke tekste is dat 'n teks altyd die produk is van 'n bepaalde sosiale sisteem. Die implikasie van hierdie uitganspunt is duidelik: Voordat daar 'n poging aangewend word om 'n bepaalde teks te verstaan, moet daar eers gepoog word om die sosiale sisteem wat die teks geproduseer het tot verstaan te bring. Wat dus nodig is, is bepaalde lees scenario's wat die interpreteerder in staat stel om die sosio-kulturele aspekte (cultural scripts of sosiale realia), wat 'agter' die gelykenisse lê, te identifiseer en bewustelik die interpretasie van die gelykenisse in ag te neem.

Die sosiaalwetenskaplike benadering stel dus nie alleen belang in 'that what was going on when and where' in tekste nie, maar veral in hoekom of waarom dit wat byvoorbeeld in 'n gelykenis beskryf word soos dit beskryf (vertel) word (Elliott 1993:1). Die fokus is dus op sosiale gedrag, sosiale groeperinge, sosiale instellings en patrone van sosiale kodifisering wat in die teks aanwesig is. Om hierdie aspekte van antieke tekste te analiseer, konstrueer dié van onder andere Mediterreense agrariese gemeenskappe, en gebruik die modelle dan om byvoorbeeld aspekte soos eer en skaamte, verhoudinge tussen beskermheer en onderdaan, diadiese persoonlikheid en etes as seremonies in antieke Mediterreense tekste te

8.'n Anakronistiese en/of etnosentriese lees van die gelykenisse vind plaas wannee die moderne interpreteerder, in die woorde van Elliott: '... reads into the text information from some present social context rather than comprehending the text in accord with its own contemporary social and cultural scripts' (Elliott 1993:11). Hierdie hermeneutiese tekort is volgens Rohrbaugh (2006:560, 563) egter net die helfte van die probleem: 'Cultural awareness of the "other" is only half of the equation when it comes to cross-cultural communication. Cultural self-awareness is equally essential if we are to understand why ... all other peoples so persistently project themselves onto the language and thinking of others. Unless we know what is peculiarly ... about the way we think and speak and how it differs from the cognitive habits and communicative styles of other cultures, we are not likely to understand why we cannot accurately hear what they ... write even when cultural knowledge of the "other" is readily available to us. In spite of our fondness for our own culture and its way of thinking/doing, the fact is that it is peculiar. It is not shared by the vast majority of those around the world and was never envisioned by those who wrote the Bible'. (Beklemtoning in dis van Rohrbaugh geld natuurlik ook wat betref die bewus wees van eie (latere) teologiese oortuigings.

9.Elliott (1993:7) definieer die sosiaalwetenskaplike benadering tot die lees van tekste soos volg: 'Social-Scientific Criticism (SSC) of the Bible is that phase of the exegetical task which analyzes the social and cultural dimensions of the text and of its environmental context through the utilization of the perspectives, theory, models, and research of the social sciences. As a component of the historical-critical method of exegesis, Social-Scientific Criticism investigates biblical texts as meaningful configurations of language intended to communicate between composers and audiences. In this process it studies not only (1) the social aspects of the form and content of texts but also the conditioning factors and intended consequences of the communication process, (2) the correlation of the text's linguistic, literary, theological (ideological), and social dimensions and (3) the manner in which this textual communication was both a reflection of and response to a specific social text cultural context, that is, how it was designed to serve as an effective vehicle and cultural context, that is, how it was designed to serve as an effective vehicle of social interaction and an instrument of social as well as literary and theological consequence'. In verband met die sosiaalwetenskaplike benadering tot die lees van antieke tekste, maak Fiensy (2007:2) die volgende opmerking wat ter sake is: 'A study of the New Testament's background or the culture of the New Testament is, therefore, not the icing on the cake of New Testament studies; it is the flour from which the cake is made. This enterprise is not a hobby one pursues in addition to the serious stuff of exegesis; it is the way the serious stuff is done.' analiseer. Verder gee die sosiaalwetenskaplike benadering ook bewustelik aandag aan die struktuur, genre, retoriek en kommunikasiestrategieë van tekste. As sodanig, omvat die sosiaalwetenskaplike benadering dus alle aspekte wat betrokke is by die kommunikasieproses: dit gee aandag aan die outeur, die teks, en die leser, met die klem op die kutuurgebondenheid van die outeur en die moderne leser. Die sosiaalwetenskaplike metode sluit dus 'n diakroniese en sinkroniese lees van die teks in, en gee ook aandag aan die resepsie van die teks.

Die sosiaalwetenskaplike benadering, ten slotte, verreken bewustelik die feit dat die gelykenisse hoëkonteks-tekste is. Elliott (1993) beskryf hierdie aspek van die gelykenisse soos volg:

[T] he New Testament ... consists of documents written in what anthropologists call a 'high context' society where the communicators presume a broadly shared acquaintance with and knowledge of the social context of matters referred to in conversation or writing. Accordingly, it is presumed in such societies that contemporary readers will be able to 'fill in the gaps' and 'read between the lines'. (bl. 11)

Die belangrikste uitdaging waarmee die interpreteerder van die gelykenisse gekonfronteer word, omdat ons hier met hoëkonteks-tekste te make het, is dat 'we do not know what we do not know' (Rohrbaugh 2006:567). Rohrbaugh (2006) maak vervolgens in hierdie verband die volgende opmerking:

The current consensus view of parables is that they are something like open-ended, extended metaphors that force the reader to arrive at conclusions of his/her own. That may or may not be accurate, but of course the missing piece is knowledge of the context. If we knew all about the setting in which these stories were first told perhaps we would get the point in the fashion a high context person would expect. But lacking it ... we arrive at conclusions that often bear no relation to an ancient context whatsoever. (bl. 567)

Die belangrikheid van die punt wat Rohrbaugh hier maak, kan nie genoeg beklemtoon word nie. Wanneer die gelykenisse geïnterpreteer word sonder dat daar in ag geneem word dat ons hier met hoëkonteks-tekste te make het, en daar nie bewustelik sosiaalwetenskaplike modelle ingespan word om die kulturele konvensies wat 'agter' 'n gelykenis lê te identifiseer en in 'n interpretasie te verreken nie, lei dit noodwendig tot 'n teologies-allegoriese (etnosentriese en/ of anakronistiese) interpretasie van die gelykenisse. In die nalees van die interpretasiegeskiedenis van enige gelykenis word hierdie aspek van die huidige interpretasie van die gelykenisse duidelik.

\section{Die gelykenisse en realisme}

Sedert die bydraes van Jülicher en Dodd neem 'n aantal gelykenisnavorsers die realistiese aspek van die gelykenisse van Jesus ernstig op. ${ }^{10}$ 'n Gelykenis, volgens Zimmermann (2007), is:

10.Kyk byvoorbeeld Hedrick (2004), Herzog (1994), Schottroff (2006) en Kloppenborg (2011:325, 2014b:556-558). 


\begin{abstract}
... 'n kort narratief wat in sy narratiewe wêreld verwys na 'n bekende realiteit, en deur implisiete of eksplisiete suggesties dit duidelik maak dat die betekenis van wat vertel word, onderskei moet word van die woorde in die teks. So lei die gelykenis die leser of hoorder om 'n metaforiese verbinding te maak tussen wat vertel word en wat die betekenis daarvan is, 'n verbinding wat gebaseer moet word op kontekstuele inligting. (bl. 25; [vry vertaal uit Duits])
\end{abstract}

Die implikasie van Zimmermann se definisie van 'n gelykenis is dat die gelykenisse realistiese narratiewe is, en dat die betekenis van 'n gelykenis gesoek moet word in die realistiese aspekte wat dit verwoord. Die gelykenisse van Jesus handel oor skape wat verlore raak, dagloners wat in 'n wingerd gaan werk, konings wat skuld afskryf, saad wat gesaai word, seuns wat die huis verlaat en persone wat ander geld skuld. Die gelykenisse handel dus nie oor verlore sondaars, regverdiging deur geloof en nie werke nie, God wat sonde vergewe, die evangelie wat verkondig word, gelowiges wat die pad van sonde begin stap of persone wat teenoor ander gesondig het nie. Anders gestel: in die gelykenisse van Jesus is 'n skaap ' $n$ skaap, ' $n$ herder is ' $n$ herder, skuld is doodgewone skuld en die eienaar van' $n$ wingerd is eenvoudig die eienaar van 'n wingerd. En, soos Zimmermann dit stel, is die betekenis van 'n gelykenis juis geleë in die alledaagse realiteite waaroor die gelykenis handel. ${ }^{11}$

Hierdie aspek van Jesus se gelykenisse maak dit van essensiële belang dat die interpreteerders van die gelykenisse hulleself eers duidelik sal vergewis van die sosiale realia of kulturele konvensies wat moontlik in 'n gelykenis aanwesig kan wees. In die woorde van Kloppenborg (2014b:2, 490):

We have to assemble solid ancient comparanda on the practices and social realities which the sayings of Jesus and the parables presuppose.... [W] ought to get clear on the most basic meanings of the images in question before moving to abstract, symbolic or allegorical meanings.

Resente navorsing oor die gelykenisse toon aan dat ons belangrikste, en soms enigste, bron om inligting in te win oor die sosiale realia wat in Jesus se gelykenisse verbeeld word, gedokumenteerde Grieks-Romeinse inskripsies en papiri uit die Vroeë Romeins-Egiptiese periode is (kyk Bazzana 2011, 2014; Kloppenborg 2006, 2011:323-351, 2014a: 287-306, 2014b:491-511, 556-576, 577-599). Hierdie papiri bied gedetailleerde inligting oor die sosiale realiteite wat in die gelykenisse verhaal word, en stel die navorser in staat om duidelikheid te kry oor die realistiese elemente wat in 'n gelykenis verhaal word. Dit stel die navorser verder in staat om, soos verwoord deur Kloppenborg (2006), die verrassende aspek te identifiseer in 'n gelykenis, waarin die betekenis van die gelykenis heel waarskynlik geleë is:

$[A] \ldots$ parable ... functions ... [as] a story that is realistic, if somewhat unusual ... that deliberately invokes certain cultural scripts or believes about the world. Then it challenges or

11. Dit is ook die standpunt van Herzog (1994:135-136): Die narratiewe repertoire van die gelykenisse is nie toevallig of irrelevant ten opsigte van die realiteite wat in' die gelykenisse is nie toevallig of irrelevant ten opsigte van die realiteite wat in 'n gelykenis aangebied word nie, maar gegrond in die verteller se sosiale, politiek en kulturele milieu. So verstaan, is die sosiale gesitueerdheid van' 'n gelykenis (die realisme wat verbeeld word), $n$ n venster na die betekenis van die gelykenis (kyk ook Scott 1990:270) problematizes those scripts and believes through an unexpected narrative turn. Narrative realism is essential, for it is only by means of a realistic idiom that the he can be induced to identify with characters in the story before the 'trap' is sprung. ${ }^{12}$ (bl. 278)

Metodologies gesproke is die implikasie dus dat daar eers bepaal moet word wat die bekende of algemene sosiale realia is wat in 'n gelykenis aan die orde gestel word. Eers dan kan daar, in die lig van die 'normale', aangetoon word wat die onverwagte of verrassende aspek van 'n spesifieke gelykenis is.

\section{Die klassifikasie van die gelykenisse}

Zimmermann se definisie van 'n gelykenis lê nie alleen klem op die realisme van die gelykenisse nie, maar lê ook die metaforiese aspek van die gelykenisse ter tafel. Sedert Jülicher se onderskeid tussen 'n vergelyking en metafoor, en sy klassifikasie van die gelykenisse as vergelykings, fabels of voorbeeldvertellings, het dit 'n gewilde stokperdjie onder gelykenisnavorsers geword om die gelykenisse in verskillende kategorieë te klassifiseer (kyk Van Eck 2009:8). Die klassifikasie van die gelykenisse, en meegaande debatte oor wat'n metafoor sou wees, is beide moderne konstrukte en 'n anakronistiese oefening wanneer die gelykenisse van Jesus die fokus van die interpretasie is. Wat wel hier van belang is, is die vraag hoe die eerste hoorders die gelykenisse gehoor het. Die eerste hoorders van die gelykenisse, waarvan die meeste heel waarskynlik ongeletterd was, het hulle wanneer 'n gelykenis aangehoor is nie eers afgevra of dit wat hulle nou hoor 'n metafoor,'n vergelyking, 'n dubbele indirekte gelykenis, 'n uitgebreide allegorie, 'n eenvoudige direkte of 'n eenvoudige indirekte gelykenis (kyk Snodgrass 2008:916 ) is voordat hulle aan ' $n$ gelykenis ' $n$ bepaalde betekenis toegeken het nie.

Jesus se gelykenisse, eenvoudig gestel, is atipiese vertellings waarin die sosiale realiteite van die leefwêreld van die hoorders - die status quo - vervang word deur'n ander wêreld, 'n wêreld wat Jesus die koninkryk van God genoem het. Vertellings funksioneer gewoonlik op een van twee wyses: dit kan óf die bestaande status quo (die dominante kultuur en aanvaarde oortuigings) onderskryf en dus bevestig, óf dit bevraagteken. Jesus se gelykenisse val in die tweede kategorie. Sy gelykenisse is vertellings wat ingedruis het teen die sosiale en godsdienstige konvensies van sy tyd, die status quo bevraagteken het, en 'n ander wêreld (die koninkryk) in die plek daarvan gestel het. Dit wat tipies of gewoon was, is vervang met wat atipies of ongewoon was: beskermhere wat meer aan dagloners betaal as wat verwag word (Matt 20:1-15), konings wat skuld vergewe (Matt 18:23-33), 'n elite wat eer opsy stoot en sosiaal veragtes na 'n ete nooi (Luk 14:16-23), 'n kleinboer wat die bietjie wat hy het met almal

12.Kyk ook die volgende opmerking van Hedrick (2004:43): 'Interpreting the parables requires knowledge of first-century Palestinian society, economics, politics, religion, and farming practices if they are to be understood in that context. Such knowledge of first-century practices evokes awareness of subtleties in the narrative missed by the heavy-handed searcher for theological ideas ... Knowledge of the social world acts as a brake to the overeager imaginations of all who mine the parables for theological insights... Readers unaware of such almost subliminal social values ar easily led astray in their readings.' Herzog (1994:84) huldig dieselfde oortuiging 'To understand the parable, it is necessary to know who appears in its social script.' 
deel sodat almal genoeg kan hê (Mark 4:3-8), 'n herder wat nie tot geweld oorgaan om vir moontlike verlore inkomste te vergoed nie (Luk 15:4-6), en 'n handelaar wat ophou om ander uit te buit (Matt 13:45-46). Jesus se gelykenisse het aan die hoorders 'n alternatiewe wêreld gebied: 'n wêreld sonder die uitbuiting van aristokratiese maghebbers en beskermhere, 'n wêreld waarin daar nie onderskeid gemaak is tussen dié wat sosiaal en kulties rein was en dié wat nie was nie. Hierdie wêreld (as nuwe realiteit) was die koninkryk van God, en omdat dit 'n 'koninkryk' was, het dit implisiet alle ander koninkryke, in besonder die koninkryke van die Romeinse Ryk en die tempel-elite, bevraagteken (kyk Van Eck 2014a:101-132). Ten slotte was hierdie koninkryk ' $n$ teenwoordige aangeleentheid, en nie iets wat eendag sou aanbreek nie; as teenwoordige koninkryk het dit ander teenwoordige koninkryke uitgedaag.

Bogenoemde beskrywing van die gelykenisse van Jesus impliseer nie dat die gelykenisse nie deur middel van ander hermeneutiese lense ondersoek kan word nie. Om die gelykenisse te bestudeer deur gebruik te maak van moderne literatuurteorieë, teorieë oor metaforisiteit of deur die lens van filosofiese kategorieë, het waarde. In hierdie soort lees van die gelykenisse moet die navorser net bewus wees dat daar resepsie-esteties met die gelykenisse omgegaan word, en die ondersoek nie ' $n$ poging aanwend om te bepaal wat Jesus, of selfs die Jesusse van die evangelies, met 'n gelykenis bedoel het nie.

\section{Toepassing: Enkele voorbeelde}

Watter resultate lewer bogenoemde metodologie wanneer die gelykenisse in die evangelies as gelykenisse van die historiese Jesus ondersoek word? In wat volg, word 'n paar voorbeelde gebruik om aan te toon wat die moontlike waarde van hierdie benadering is.

Die gelykenis van die Verlore Skaap (Luk 15:4-6) word oorwegend deur gelykenisnavorsers geïnterpreteer as 'n illustrasie van God se genade, vergifnis, of liefde vir die verlore sondaar. Hierdie interpretasies is allegories. Wanneer die herder as 'n simboliese verwysing na God of Jesus gesien word, en die skaap as 'n simboliese referent vir 'n verlore sondaar, kan daar moeilik tot 'n ander lees van die gelykenis gekom word. Wanneer die herder en skaap egter nie as simboliese verwysings gesien word nie, bied gedokumenteerde papiri en Vroeë Romeinse en Laat Hellenistiese bronne belangrike inligting wat dit moontlik maak om die gelykenis te interpreteer in die lig van die sosiale en ekonomiese realia (registers) wat heel waarskynlik 'agter' die gelykenis lê, en onontbeerlik is om dit te verstaan.

In die eerste plek dui inligting uit gedokumenteerde papiri daarop dat in die tyd van Jesus dit algemene praktyk was vir eienaars van skape om herders te kontrakteer om na hulle skape om te sien. ${ }^{13}$ Die betrokke papiri toon aan dat skape meestal in afgeleë en onherbergsame gebiede gewei het; dat 'n trop skape normaalweg uit ongeveer vyftig tot honderd skape (plus 'n paar bokke) bestaan het; dat die loon van herders so laag was as min of meer sestien dragma per maand (dus laer as die loon van 'n dagloner, rioolskoonmaker, waterdraer of muildrywer en minder as die helfte van die loon van 'n skrynwerker, steenwerker of bakker; kyk Rust. 2.10.3; P.Lond. III 1171); dat die waarde van 'n ooi en ram respektiewelik twintig en tien dragma beloop het (kyk bv. SB XX 14525), en dat die herder verantwoordelik was vir enige skade (bv. skape wat weggeraak het; kyk P.Amst. I 41). Indien 'n ooi verlore sou raak, het dit dus beteken dat 'n herder meer as 'n maand se inkomste verloor het. Ten slotte toon beskikbare bronne aan dat herders as ongewenste persone beskou is. Die herdersberoep is as veragtelik beskou, en herders is geassosieer met tollenaars, kon nie as getuies in 'n dispuut optree nie, is beskou as rowers, onrein (saam met beroepe soos houtkappers, muildrywers, en handelaars), en in beginsel oneerlik - daarom ' $n$ beroep wat deur Jode so ver as moontlik vermy is. Gedokumenteerde papiri toon verder aan dat herders, omdat hulle nomadies was, sonder toesig, en bewapen was met ' $n$ slinger en herderstok, as rowers beskou is.

Met hierdie inligting as agtergrond, wat heel waarskynlik bekend was by die eerste hoorders van die gelykenis, word nuwe perspektiewe geopen wat die navorser in staat stel om vanuit 'n ander hoek na die gelykenis van die Verlore Skaap te kyk. Eerstens is dit duidelik dat die gelykenis nie oor God en sondaars handel nie, maar oor die benarde sosioekonomiese situasie waarin herders (en heel waarskynlik ook die hoorders van die gelykenis), verkeer het. Inligting uit beskikbare papiri suggereer die rede waarom die herder bereid is om nege-en-negentig skape te los om een verlore skaap te gaan soek; dit gaan eenvoudig oor ekonomiese oorlewing. Indien die herder sy gesin wil versorg, en dit byvoorbeeld ' $n$ ooi is wat weggeraak het, het hy geen ander keuse as om die verlore skaap te gaan soek nie. Die optrede van die herder, wat deur die meeste interpreteerders as 'onverklaarbaar' en onrealisties beskou word, is dus realisties en verstaanbaar. Verder stel die beskikbare inligting die interpreteerder in staat om raak te sien dat tussen die vind van die skaap, en die herder se tuiskoms, tyd moes verloop het, aangesien die herder eers sy kontrak met die eienaar moes voltooi het voordat hy kon terugkeer na sy huis. Ten slotte verklaar dit ook die rede vir die feesviering: Omdat die herder in staat was om die verlore skaap te vind is hy sodanig besoldig dat hy en sy huisgesin ten minste vir nou genoeg gehad het om te oorleef.

Wat wou Jesus heel waarskynlik met die gelykenis oor die koninkryk kommunikeer? Dalk dat die koninkryk ook beskikbaar was vir die sogenaamde 'veragtes' en 'onreines'; dat die koninkryk veral gevind kan word waar so opgetree word dat almal genoeg het; en dat die koninkryk sigbaar in

$356=S B$ XVI 12761 (27 n.C.); P.OXY. $11353(27-28$ n.C.) P.Oxy. $11351=S B$ XII 10795 (28 n.C.); P.Oxy. $/ / 355=$ = SB XVI 12763 (40-41 n.C.); P.Ross.Georg. $\| 13$ (54-68 n.C.);

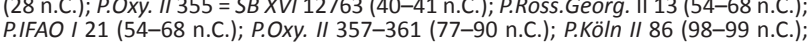
P.Phil. 8 (136/7 n.C.) en P.Oxy. XLVII 3338 (150 n.C.). 
die onverwagte is. Die verwagte optrede van 'n herder sou wees om deur middel van geweld (bv. roof) of oneerlikheid vir sy verlies te vergoed. Maar nie die herder in die gelykenis nie. Teen alle verwagtinge in gaan soek hy die verlore skaap terwyl hy die ander skape onbewaak laat, en omdat hy die skaap vind, het almal genoeg. In hierdie verband moes Jesus se gebruikmaking van die beeld van' $n$ herder, om iets van die koninkryk te verbeeld, vir sy hoorders skokkend gewees het. Die moderne interpreteerder van die gelykenis lees hierdie aspek van die gelykenis maklik mis omdat die herder gesien word in die lig van die positiewe beeld van herders in die $\mathrm{Ou}$ Testament (wat in 'n nomadiese, en nie gevorderde agrariese wêreld nie, geleef het). Hierdie aspek van die gelykenis bevestig ook dat dit tipies van Jesus was om die koninkryk in sy gelykenisse te vergelyk met die optredes van sogenaamde ongewenste karakters (kyk bv. ook die gelykenis van die Handelaar; Van Eck 2015c). ${ }^{14}$

Die gelykenis van die Werkers in die Wingerd (Matt 20:1-13) sluit by laasgenoemde tema aan; ook hier het ons te make met 'n ongewenste karakter. Soos in die geval van die Verlore Skaap, is die meeste verklarings van hierdie gelykenis allegories. In die besonder is twee verklarings van die gelykenis algemeen: Die eienaar van die wingerd word as 'n simbool vir God gesien, met die gevolg dat die gelykenis nie eintlik anders verstaan kan word as sou dit iets wil sê van God se genade en barmhartigheid nie. Die tweede algemene verklaring, wat met eersgenoemde saamhang, is om die gelykenis deur ' $n$ heilshistoriese bril te lees. Die werkers wat vroegoggend begin werk, verteenwoordig die Jode, en dié wat later gaan werk, die nie-Jode. Gelees deur hierdie bril, en in die lig van die vroeë werkers wat kla omdat almal dieselfde loon ontvang, dui die gelykenis daarop dat verlossing nie deur werke verkry word nie, 'n duidelike teologies- allegoriese interpretasie.

Inligting wat beskikbare papiri bied, dui daarop dat ons in hierdie gelykenis te make het met wat tipies was van wynbou in die tyd van Jesus. Die gelykenis neem dit as vanselfsprekend dat die beste landbougrond in die tyd van Jesus besit is deur elite wat op groot skaal geboer het met die oog op uitvoer en nie plaaslike verbruik nie. ${ }^{15}$ Hierdie landbougrond het vroeër aan kleinboere behoort wat met graan, druiwe en olywe (en soms vye) vir eie gebruik geboer het. Baie van hierdie kleinboere het egter hulle grond verloor weens (politieke) beslaglegging ${ }^{16}$ of skuld. Elite het dan hierdie kleiner plotte saamgevoeg en dit in wingerde omskep met die oog op die verbou van wyn, gemik op die uitvoermark $^{17}$ (kyk ook Josefus, Ant. 15.264, 17.305-307;

14.Vir'n meer volledige interpretasie van die gelykenis van die Verlore Skaap, asook die bronne wat vir hierdie interpretasie gebruik is, kyk Van Eck (2011:1-10)

15.Kyk byvoorbeeld P.Lond VII 1948; P.SI VI 554; P.Köln III 144; P.Cair.Zen II 59162, IV 59186; P.Fouad I 43; P.Hamb I 23 en P.Laur IV 166 (kyk ook Plinius, Hist. nat. 17.171; De re rustica $3.13,5.3$ ).

16.Kyk P.Mich III 200; P.SI 518, 554, 689 en P.Cair.Zen II 59173.

17.Vir getuienis oor landbougrond wat voorheen gebruik is vir die verbouing van graan, olywe en druiwe, ingepalm is en omgesit is in grootskaalse wynbou, kyk P.Lond II 483, VII 1948; BGU IV 1122, XII 2177; P. Mich 9229; P.Mil.Vogl II 69, VII 308 P.Cair.Masp I 67097; P.Col.Zen II 79; P.Flor II 134; P.Oxy IV 707; P.Ryl II 427; P.SI VI 554; P.Cair.Zen II 59162, IV 59816, en P.Köln III 144.
Vita 33, 47, 115, 422, 429; Bell 1.403-405, 3.36). Die verlies van grond en fokus op wynbou met die oog op uitvoer, het ' $n$ negatiewe effek op kleinboere gehad in soverre dat die meeste van hulle óf huurders óf dagloners geword het. Werk was skaars, en dagloners kon die meeste van die tyd net seisoenale werk bekom, ${ }^{18}$ veral tydens die oestyd. Gedokumenteerde inskripsies en papiri dui verder daarop dat die eienaars van wynlandgoedere welaf was, aangesien lone, die aankoop van implemente, en die omskakeling tot grootskaalse wynbou aansienlike kapitale inset vereis het. ${ }^{19}$ Ook was dit normaal dat eienaars van agente, wynmakers en bestuurders gebruik gemaak het om namens hulle wynplase te bestuur. ${ }^{20}$ Dit was dus normaal dat 'n eienaar afwesig van sy landgoed was. ${ }^{21}$

'n Sinvolle interpretasie van die gelykenis behoort daarom aan die volgende aspekte aandag te gee: Hoekom gaan die eienaar, wat afwesig behoort te wees en oor die dienste van 'n bestuurder beskik, wat gewoonlik na werkers (en veral dagloners) omgesien het, self na die markplein om werkers te huur? Wie is die persone wat as dagloners gehuur word? Hoekom kom die eienaar net met die werkers wat hy eerste huur (om sesuur die oggend) op 'n bepaalde dagloon ooreen, en nie met die werkers wat deur die loop van die dag (tot so laat soos vyfuur) gehuur word nie? Hoekom word dié wat laaste begin werk het, eerste betaal, en diegene wat eerste begin het, laaste? En, ten slotte, word die eienaar in die gelykenis as 'n positiewe of negatiewe figuur uitgebeeld?

Hierdie vrae, wat nie deur die meeste interpreteerders gevra word nie, en waar dit wel gevra word, daar erken word dat die vrae nie werklik beantwoord kan word nie, kan sinvol ontleed word in die lig van genoemde papiri, asmede deur die gebruik van die sosiaalwetenskaplike modelle wat handel oor die verhoudinge tussen beskermheer en onderdaan, en die persepsie van beperkte middele. In die eerste plek is die teenwoordigheid van die eienaar ongewoon, 'n aspek van die gelykenis wat deur net enkele interpreteerders uitgelig word. Verder sou die blote feit dat Jesus 'n gelykenis begin waarin hy die koninkryk vergelyk met die optrede van 'n landgoedeienaar sy hoorders geskok het. Landgoedeienaars was welaf, en rykdom, so is geglo, in terme van hulle persepsie van beperkte middele is alleen bekom ten koste van ander. Ryk persone is beskou as diewe en inherent boos. Verder het die hoorders die eienaar heel waarskynlik beskou as die oorsaak van hulle eie benarde sosio-ekonomiese situasie (verlies van grond).

18.Oor seisoenale werk in wingerde, kyk P.Heid ili 326; P.Oxy XIV 1631, 1692; P.Col.Zen I 59103. II 79; IV 59176, 59548, 59549 en P.Zen.Pestm 64

19.Oor papiri wat die welvaart van wingerdeienaars bevestig, kyk P.Lond VII 1948; P.SI XIII 1338, VI 554; P.Köln III 144; P.Cair.Zen II 59162, IV 59186; BGU IV 1122; P.Oxy XIV 1631, 1692, XLVII 3354, XLIX 3464; P.Duke 749; P.Ber/Leihg I 23 en P.Flor II 148.

20.Kyk byvoorbeeld P.Mich X 601; P.Gur 8; P.RyI IV 583; P.Köln III 144; BGU IV 1122; P.Oxy XIV 1631, XIV 1692; XLVII 3354, XLIX 3464; P.Harr I 137; P.Ber/Leihg I 23; P.SI
IV 372; P.SI XIII 1338; CPR XVIIA 6; P.Cair.Zen I 59018; P.Col X 284 en P.Petr I 29, II 30, III $67 \mathrm{~b}$.

21.Kyk inter alia P.Cair.Zen III 59300; P.Yadin 42; P.Mur 24A-K; BGU II 636; IV 1122, IV 1125, P.Oxy LVII 3911; P.RyI II 168; IV 600; P.SI X 1095; P.Tebt I 107; P.Petr III 73; P.Soter 2 en P.Lond VII 1981 en 2188. 
Die hoorders se aanvanklike beeld van die eienaar verander egter algaande die gelykenis ontwikkel. Omdat dit heel waarskynlik oestyd was, huur die eienaar werkers tot vyf uur die middag. Alhoewel die meeste interpreteerders van die gelykenis hierdie optrede van die eienaar as onrealisties beskou, dui die inligting wat dokumentêre papiri ons bied daarop dat dit inderdaad realisties is. Dit was oestyd, en tydens oestyd is abnormaal baie werkers benodig. Aan die einde van die gelykenis, wanneer dit kom by die betaal van die werkers, gee die eienaar sy bestuurder opdrag om almal, in omgekeerde volgorde, dieselfde loon te betaal. Die meeste interpreteerders is dit eens dat die eienaar, met hierdie optrede, as positief uitgebeeld word. Die werkers wat eerste begin werk het, ontvang hulle ooreengekome loon, en dié wat later begin werk het, ontvang heel waarskynlik meer as wat hulle verwag het. Maar hoekom word dié wat later begin werk het, eerste betaal? Die meeste navorsers oordeel dat hierdie aspek van die gelykenis onrealisties is en nie werklik sinvol verklaar kan word nie. Gesien vanuit 'n sosiaalwetenskaplike hoek, is die verklaring heel waarskynlik dat daar tussen die eienaar en die werkers wat later begin werk het, ' $n$ reeds bestaande verhouding van beskermheer en onderdaan in plek was. Indien wel die geval, verklaar dit hoekom die eienaar nie met hulle oor 'n loon ooreengekom het toe hulle gehuur is nie, en ook hoekom hulle eerste betaal word. As beskermheer, was dit van hom verwag om sy onderdane te bevoordeel.

Ondanks hierdie 'bevoordeling' skets die gelykenis die eienaar as positief. Sy optrede is tipies van die koninkryk: Hy is 'n voorbeeld van hoe beskermhere behoort op te tree (almal kry genoeg). Bowenal is hy díkaıs (Matt 20:4). Volgens Jesus is die beskermheer dus, in lyn met die profetiese tradisie in die Ou Testament, iemand wat seker maak dat die weerloses in die gemeenskap genoeg het om te leef en oorleef (vgl. bv. Jes. $\operatorname{LXX} 1: 17$; Jer. $\operatorname{LXX} 7: 6,22: 3)$. In hierdie opsig is hy 'n voorbeeld vir ander beskermhere, wat soos hy, ook bereid behoort te wees om verantwoordelikheid te aanvaar vir hulle wat nie het nie. ${ }^{22}$

Daar hoef nie met hierdie interpretasie van die gelykenis saamgestem te word nie, maar een saak staan tog uit. Alleen wanneer die gelykenis teen die agtergrond gelees word van die sosiale realia wat deur die gelykenis opgeroep word, en wat heel waarskynlik aan die hoorders van die gelykenis bekend was, kan daar met oortuiging geargumenteer word watter aspekte van die gelykenis as realisties en watter as ongewoon beskou behoort te word. En hiervoor is die inligting van beskikbare papiri ons bied, onmisbaar.

As laaste voorbeeld kan daar in kort na die gelykenis van die Onvergewensgesinde Slaaf (Matt 18:23-33) verwys word. Soos in die geval van die gelykenisse van die Verlore Skaap en die Werkers in die Wingerd, word hierdie gelykenis deur die meeste gelykenisnavorsers teologies- allegories geïnterpreteer: In navolging van Origenes is die meeste

22.Vir' $n$ uitgebreide interpretasie van die gelykenis van die Werkers in die Wingerd, asook argumente wat bogenoemde gevolgtrekkings ondersteun, kyk Van Eck en Kloppenborg (2015). interpretasies dit eens dat die koning in die gelykenis as 'n simboliese verwysing na God verstaan moet word. Met hierdie vertrekpunt, kan die interpretasie van die gelykenis nie 'n ander uitkoms hê as dat die skuld van die twee amptenare na sonde verwys nie, met die oorkoepelende interpretasie dat God nie sondaars se skuld sal vergewe indien hulle nie bereid is om mekaar te vergewe nie.

Gelees in die lig van beskikbare papiri en inskripsies is daar egter 'n ander moontlike interpretasie van die gelykenis (kyk Van Eck 2015b). Wanneer die gelykenis met papiri soos P.Köln 7.313 en SB 20.14106, en die apokrief 1 Makkabeërs 13:36-39 vergelyk word, is daar merkwaardige ooreenkomste te bespeur. In die eerste plek word daar in die genoemde papiri en 1 Makkabeërs presies dieselfde woorde (die woordgroep ỏ $\varphi \varepsilon i ́ \lambda \omega$ en ả $\varphi$ í $\mu$ i) gebruik as in die gelykenis om onderskeidelik na skuldenaars ${ }^{23}$ en die afskryf van skuld ${ }^{24}$ te verwys. Verder is die inhoudelike ooreenkomste opvallend. P.Köln 7.313 het as inhoud 'n koninklike dekreet van koning Ptolemeus V waarin alle skuld van onderdane afgeskryf word. Die inhoud van SB 20.14106 kom op dieselfde neer: Koning Ptolemeus en sy vrou Kleopatra skryf, onder andere, alle skuld af wat uitstaande is ten opsigte van belasting op oeste. Die inhoud van 1 Makkabeërs 13:36-39 het dieselfde strekking: In 'n dekreet gerig aan die hoëpriester Simon, die familiehoofde en die inwoners van Joodse Palestina, onderneem Demetrius II (die nuwe Seleusidiese koning), om alle uitstaande skuld van die tempel en alle ander uitstaande belasting wat in Jerusalem gevorder is, af te skryf. Interessant is ook dat in P.Münch 3/1.45.2, UPZ 1.113.6, P.Tor.Choach. 12.7.14 en $B G U$ 8.1764.1, 5 hierdie afskryf van skuld deur Hellenistiese koning aan die begrip basileia verbind word.

Indien veronderstel word dat hierdie kwytskeldings van die skuld van onderdane deur konings die agtergrond (sosiale realia) is waarteen die hoorders van die gelykenis na die gelykenis geluister het, is die koning se kwytskelding van die amptenaar wat hom 'n groot bedrag geskuld het, nie die verrassende element in die gelykenis nie soos feitlik alle interpreteerders van die gelykenis beweer. Wat wel verrassend sou wees, is die optrede van die amptenaar wie se skuld afgeskryf is teenoor 'n medeamptenaar wat hom veel minder geskuld het. In terme van die verhouding tussen beskermheer en onderdaan het die betrokke konings hulleself as die beskermhere van hulle nuwe onderdane gesien. Vir beskermhere was eer - die grondwaarde van en skaarsste middel in gevorderde agrariese samelewings - die belangrikste bate wat iemand kon hê of bekom. Dit was dan ook die rede waarom almal se skuld afgeskryf is; die konings se smagting na eer is bevredig (ook bekend as philotimiā). Die promulgasies in die genoemde papiri en 1 Makkabeërs het daarom 'n voorwaarde ingesluit: Soos die konings hulle onderdane se skuld afgeskryf het, is van onderdane verwag om mekaar se skuld af te skryf. Dit sou nie alleen 'n teken van 'n nuwe basileia wees nie, maar bydra tot die

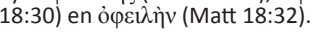

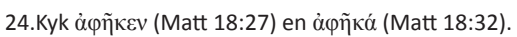


vermeerdering van die eer van die betrokke konings. Soos in alle verhoudinge tussen beskermheer en onderdaan was die verwagting resiprositeit: in hierdie geval die afskryf van mekaar se skuld as eerbetoning aan die beskermheer.

Wat vir die hoorders van die gelykenis die verrassendste sou gewees het, is die koning se optrede nadat hy in kennis gestel word van die optrede van sy amptenaar (onderdaan). Indien aanvaar word dat die gelykenis by Matteus 18:33 eindig (kyk Van Eck 2015b), sou die verwagting wees dat die koning, om sy eer te beskerm, hardhandig met die amptenaar sou omgaan. Die koning doen dit egter nie. Al wat hy doen, is om die amptenaar te betig met 'n vermaning dat die amptenaar, in navolging van sý voorbeeld, sy medeamptenaar se skuld moes afgeskryf het. Hiermee suggereer die koning, teen alle verwagting in, dat eer nie verkry word deur gebalanseerde resiprositeit (quid pro quo) nie, maar in die blote afskryf van ander se skuld. Met die gelykenis stel Jesus dit dus dat daar in die koninkryk opgetree behoort te word soos die koning: In die koninkryk word eer nie verkry deur die resiproke optrede van ander nie, maar is eer geleë in wat vir ander gedoen kan word. Anders gesê: In die koninkryk geld algemene resiprositeit (gee sonder om terug te verwag; vgl. $Q$ 6:27-28, 29, 30 en $Q$ 6:33). Eer kom diegene toe wat aan ander goed doen.

\section{Slotopmerkings}

Die vroegste literêr beskikbare, allegoriese interpretasies van die gelykenisse van Jesus is dié van die Sinoptici, en nie die allegoriese interpretasies van die vroeë kerkvaders nie. Hierdie oortuiging is essensieel vir die interpretasie van die gelykenisse indien dit ondersoek wil word as gelykenisse van Jesus: Die interpretasie behoort te begin deur die gelykenisse in hulle sosiale konteks, en nie literêre konteks nie, te ondersoek. In hierdie ondersoek moet die navorser ook bedag wees op die eie sosiale konteks. Die vraag is nie hoe die moderne interpreteerder die gelykenisse hoor nie, maar hoe hulle aan wie Jesus sy gelykenisse vertel het, die gelykenisse gehoor het.

In die interpretasie van die gelykenisse van die historiese Jesus is dit dus van uiterste belang om te bepaal, natuurlik in soverre dit moontlik is, wat die sosiale registers en ervaring (sosiale repertoire of sosiale realia) van die eerste hoorders was, en watter van hierdie sosiale registers deur 'n betrokke gelykenis opgeroep is. In die bepaling van hierdie sosiale realia blyk inligting wat gedokumenteerde inskripsies en papiri, asook Vroeë Romeinse en Laat Hellenistiese bronne ons bied, van onmisbare waarde te wees. Die GrieksEgiptiese papiri, en die papiri van die Arava, span oor 'n tydperk wat eerste-eeuse Palestina insluit, en dui op dieselfde sosiale strata en prosesse. Met die inagneming van wetlike en kulturele verskille, bied hierdie papiri en inskripsies aan ons waardevolle - en soms die enigste - inligting oor die kulturele leefwêreld van Jesus en die hoorders van sy gelykenisse, asook die sosiale realia wat in die gelykenisse as bekend veronderstel word (Kloppenborg 2014a:289). Gekombineer met 'n sosiaalwetenskaplike benadering tot tekste, wat poog om hierdie sosiale realia kultuursensitief te verstaan, kan daar dalk sinvol en verantwoordelik met Jesus se gelykenisse omgegaan word.

Gelees aan die hand van bogenoemde metodologie kan die gelykenisse van Jesus gesien word as simbole wat sosiale transformasie beskryf. Die gelykenisse is vertellings wat die bekende omkeer tot iets anders en iets nuuts. In die plek van die bestaande wêreld en ervaring van die hoorders teken die gelykenisse prentjies van hoe die wêreld kan en behoort te wees. In die woorde van Herzog (1994:3): '[T]he parables were not earthly stories with heavenly meanings, but earthly stories with heavy meanings'.

\section{Erkenning Mededingende belange}

Die outeur verklaar dat hy geen finansiële of persoonlike verhouding het wat hom positief of negatief kon beïnvloed het met die skryf van hierdie artikel.

\section{Literatuurverwysings}

Bazzana, G.B., 2011, 'Basileia and debt relief: The forgiveness of debts in the Lord's Prayer in the light of documentary papyri', The Catholic Biblical Quarterly 73, 511-525.

Bazzana, G.B., 2014, 'Violence and human prayer to God in Q 11', HTS Teologiese Studies/Theological Studies 70(1), Art. \#2733, 8 pages. http://dx.doi.org/10.4102/ hts.v70i1.2733

Blomberg, C.L., 2012, Interpreting the parables, InterVarsity Press, Downers Grove, IL. Dodd, C.H., 1961, The parables of the kingdom, Charles Scribner's Sons, New York, NY. Elliott, J.H., 1993, What is social-scientific criticism?, Fortress Press, Minneapolis, MN. (Guides to Biblical Scholarship.)

Fiensy, D., 2007, Jesus the Galilean: Soundings in a first century life, Gorgias Press, Piscataway, NJ.

Hedrick, C.W., 2004, Many things in parables: Jesus and his modern critics, Westminster John Knox Press, London.

Herzog, W.R., 1994, Parables as subversive speech: Jesus as pedagogue of the oppressed, Westminster, Louisville, KY.

Hultgren, A.J., 2000, The parables of Jesus: A commentary, William B. Eerdmans Publishing Company, Grand Rapids, MI.

Jeremias, J., 1972, The parables of Jesus, SCM Press Ltd., London.

Kloppenborg, J.S., 2006, The tenants in the vineyard: Ideology, economics, and agrarian conflict in Jewish Palestine, Mohr Siebeck, Tübingen. (Wissenschaftliche Untersuchungen zum Neuen Testament 195.)

Kloppenborg, J.S., 2011, 'The representation of violence in Synoptic parables, in E-M. Becker \& A. Runesson (eds.), Mark and Matthew I. Comparative readings: Understanding the earliest gospels in their first-century settings, pp. 323-351, Mohr Siebeck, Tübingen.

Kloppenborg, J.S., 2014a, 'The parable of the burglar in Q: Insights from papyrology', in D.T. Roth, R. Zimmermann \& M. Labahn (eds.), Metaphor, narrative, and parables in Q, pp. 287-306, Mohr Siebeck, Tübingen.

Kloppenborg, J.S., 2014b, Synoptic problems: Collected essays, Mohr Siebeck, Tübingen. (Wissenschaftliche Untersuchungen zum Neuen Testament 329.)

Malina, B.J., 1981, The New Testament world: Insights from cultural anthropology, Westminster John Knox Press, Louisville, KY.

Malina, B.J., 1986, Christian origins and cultural anthropology: Practical models for biblical interpretation, John Knox Press, Atlanta, GA.

Malina, B.J. \& Rohrbaugh, R.L., 2003, Social science commentary on the Synoptic gospels, Fortress Press, Minneapolis, MN.

Rohrbaugh, R.L., 2006, 'Hermeneutics as cross-cultural encounter: Obstacles to understanding', HTS Teologiese Studies/Theological Studies 62(2), 559-576. http://dx.doi.org/10.4102/hts.v62i2.365

Schottroff, L., 2006, The parables of Jesus, transl. L.M. Maloney, Fortress Press, Minneapolis, MN.

Scott, B.B., 1990, Hear then the parable: A commentary on the parables of Jesus, Fortress Press, Minneapolis, MN.

Snodgrass, K.R., 2000, 'From allegorizing to allegorizing: A history of the interpretation of the parables of Jesus', in R.N. Longenecker (ed.), The challenge of Jesus parables, pp. 3-29, William B. Eerdmans Publishing Company, Grand Rapids, MI.

Snodgrass, K.R., 2008, Stories with intent: A comprehensive guide to the parables of Jesus, William B. Eerdmans Publishing House, Grand Rapids, MI. 
Van Eck, E., 2007, 'The tenants in the vineyard (GThom 65/Mark 12:1-12): A realistic and social-scientific reading', HTS Teologiese Studies/Theological Studies 63(3) 909-936. http://dx.doi.org/10.4102/hts.v63i3.233

Van Eck, E., 2008, 'Jesus en geweld: Markus 12:1-12 (en par.) en Thomas 65', Hervormde Teologiese Studies 64(4), 1735-1765. http://dx.doi.org/10.4102/hts. v64i4.100

Van Eck, E., 2009, 'Interpreting the parables of the Galilean Jesus: A social-scientific approach', HTS Teologiese Studies/Theological Studies 65(1), Art. \#308, 12 pages. http://dx.doi.org/10.4102/hts.v65i1.308

Van Eck, E., 2011, 'In the kingdom everybody has enough - A social-scientific and realistic reading of the parable of the lost sheep', (Lk 15:4-6)', HTS Teologiese Studies/Theological Studies 67(3), Art. \#1067, 10 pages. http://dx.doi. org/10.4102/hts.v67i3.1067

Van Eck, E., 2014a, 'Mission, identity, and ethics in Mark: Jesus, the patron for outsiders', in J. Kok, T. Nicklas, D.T. Roth \& S.M. Hays (eds.), 'Sensitivity towards outsiders', pp. 101-132, Mohr Siebeck, Tubingen. (Wissenschaftliche Untersuchungen zum Neuen Testament 2. Reihe 364.

Van Eck, E., 2014b, 'The harvest and the kingdom: An interpretation of the Sower (Mk $4: 3 b-8)$ as a parable of Jesus the Galilean', HTS Teologiese Studies/Theological Studies 70(1), Art. \#2715, 10 pages. http://dx.doi.org/10.4102/hts.v70i1.2715
Van Eck, E., 2015a, 'Memory and historical Jesus-studies: Formgeschichte in a new dress', HTS Teologiese Studies/Theological Studies 71(1), Art. \#2837, 10 pages. http://dx.doi.org/10.4102/hts.v71i1.2837

Van Eck, E., 2015b, 'Honor and debt release in the parable of the Unmerciful Servant (Mt 18:23-33): A social-scientific and realistic reading', HTS Teologiese Studies/ Theological Studies 71(1), Art. \#2838, 11 pages. http://dx.doi.org/10.4102/hts. v71i1.2838

Van Eck, E.,2015c, 'When an outsider becomes an insider: A social-scientific and realistic reading of the Merchant (Mt 13:45-46), HTS Teologiese Studies/Theological Studies 71(3), Art. \#2859, 8 pages. http://dx.doi.org/10.4102/hts.v71i3.2859

Van Eck, E \& Kloppenborg. J.S., 2015, 'An unexpected patron: A social-scientific and realistic reading of the parable of the Vineyard Labourers (Mt 20:1-15), HTS Teologiese Studies/Theological Studies 71(1), Art. \#2883, 11 pages. http://dx.doi. org/10.4102/hts.v71i1.2883

Wailes, S.L., 1987, Medieval allegories of Jesus' parables, Berkeley, University of California Press.

Zimmermann, R., 2007, Die Gleichnisse Jesu: Eine Leseanleitung zum Kompendium, in R. Zimmermannet al. (eds.), Kompendium der Gleichnisse Jesu, 3-45, Gütersloher Verlagshaus, München. 